\title{
Potential of natural repellents methylanthranilate and anthraquinone applied on maize seeds and seedlings against house sparrow (Passer domesticus) in captivity
}

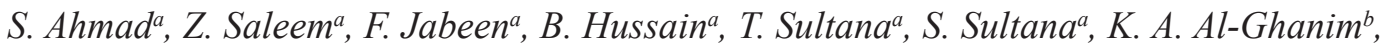 \\ N. M. A. Al-Mulhim ${ }^{b}$ and S. Mahboob ${ }^{b}$ \\ aDepartment of Zoology, Government College University, Faisalabad, 38000, Pakistan \\ ${ }^{b}$ Department of Zoology, College of Science, King Saud University, Riyadh 11451, Saudi Arabia \\ *e-mail: shahidmahboob60@hotmail.com
}

Received: November 8, 2016 - Accepted: April 26, 2017 - Distributed: November 30, 2018

(With 2 figures)

\begin{abstract}
Various bird pests caused severe economic losses to valuable crops and fruit orchards all over the world. Among the birds, house sparrow is also considered to cause heavy plunder, not only to seeds of crops but also seedlings especially in organic farming. In present study two bird repellents, methylanthranilate and anthraquinone tested against house sparrows on maize seeds and seedlings in aviary conditions. Trial group in aviary-I, the treated maize seeds and seedlings with different doses of both bird repellents, control group in aviary-II, untreated seeds and seedlings were provided for three hours in the early morning. In each aviary, two closed circuit cameras were also installed to monitor the behavioral responses against different concentrations of both chemical repellents. Statistical analysis showed that there existed highly significant $(\mathrm{P}<0.01)$ variations among the trial and control groups for seeds and seedlings. By comparing both repellents, significant $(\mathrm{P}<0.05)$ differences were detected and anthraquinone showed better efficacy when compared to methylanthranilate, but in maize seedlings both repellents equal repellent properties. Non-significant $(\mathrm{P}>0.05)$ differences were observed in different grading of both natural chemical repellents for maize seeds while significant $(\mathrm{P}<0.05)$ variations were noticed for maize seedlings when provided to sparrows. By videotaped behavior sparrows presented manifest head juddering and feather upsetting activities by consumption of treated seeds and seedlings with higher concentrations of both natural bird repellents.
\end{abstract}

Keywords: house sparrow, anthraquinone, methylanthranilate, repellent, maize.

\section{Potencial de repelentes naturais, metilantranilato e antraquinona aplicados em sementes de milho e mudas contra o pardal (Passer domesticus) em cativeiro}

\section{Resumo}

Várias pragas de aves causaram graves perdas econômicas para cultivos valiosos e pomares de frutas em todo o mundo. Entre os pássaros, o pardal da casa também é considerado um grande saqueo, não só para as sementes das culturas, mas também para as mudas, especialmente na agricultura orgânica. No presente estudo, dois repelentes de aves, metilantranilato e antraquinona testados contra pardais de casa em sementes de milho e mudas em condições de aviário. O grupo de ensaio em aviary-I, as sementes de milho tratadas e as mudas com diferentes doses de repelentes de aves, grupo de controle em aviary-II, sementes não tratadas e mudas foram fornecidas por três horas no início da manhã. Em cada aviário, duas câmeras de circuito fechado também foram instaladas para monitorar as respostas comportamentais contra diferentes concentrações de ambos os repelentes químicos. A análise estatística mostrou que existiam variações altamente significativas $(\mathrm{P}<0,01)$ entre os grupos de teste e controle para sementes e mudas. Ao comparar os dois repelentes, detectaram-se diferenças significativas $(\mathrm{P}<0,05)$ e a antraquinona apresentou maior eficácia quando comparada ao metilantranilato, mas em mudas de milho, ambos os repelentes são iguais às propriedades repelentes. As diferenças não significantes $(\mathrm{P}>0,05)$ foram observadas em diferentes classificações de repelentes químicos naturais para sementes de milho, enquanto as variações significativas $(\mathrm{P}<0,05)$ foram observadas para as mudas de milho quando fornecidas aos pardais. Por um comportamento gravado em video, os pardais apresentaram manifestações de cabeça e vibrações de penas por consumo de sementes tratadas e mudas com maiores concentrações de repelentes de aves naturais.

Palavras-chave: pardal da casa, antraquinona, amilananilato de metilo, repelente, milho. 


\section{Introduction}

The agriculture sector is a major source of income for $52 \%$ of the population in Pakistan and has a key role in the uplift of the economy of this state. Basically $67.5 \%$ peoples inhabiting rural areas are indirectly or directly implicated in agriculture not only for the foodstuff to the population, but also provide a variety of raw materials for industrial sectors. In Pakistan major crops are sugarcane, wheat, maize, rice, cotton (Economic Survey of Pakistan, 2013) and forage crops for animals contribute largely in country GDP. In this state crop yield per hectare is one fourth than developed countries. This is due to the fact that there is unawareness of peoples to modern techniques and lack of modern scientific equipment. There is also lack of concern about different advance techniques of crop and pest management.

Agricultural landscape promotes valued crops in various countries but very little information is available about negative effects because seed predation by various birds (Schackermann et al., 2014). Damage to maize introduced by granivorous birds takes place in various valued crops in different region of the world, including Australia, China, Europe, India, North America, Pakistan, Russia, South America, and Ukraine (Linz and Hanzel, 1997). This damage has been being not in ripe fruits and crops but also at seed and seedling stages (Ahmad et al., 2016). Humans have been cultivating maize (Zea mays) since long period of time. It was first cultivated as a wild grass named teosinte about 7000 years ago in Central Mexico. According to Tollenaar and Dwyer (1999), on the basis of area of cultivation and yield, maize has become the third important crop after rice and wheat globally. Maize cultivated for fodder is a temporary crop and can be harvested in around 8-10 weeks' after it is cultivated.

Vertebrate pests are responsible for significant seasonal damages to natural resources, agricultural crops. This damage not only reduces the productivity, but also affect human health due to food shortage throughout the world. Birds and mammals are the major vertebrate groups no doubt cause serious damage the valuable seasonal crops but also fruit orchards. Fruit and cereal crops are seriously affected by the birds. The damage in these crops varies in different fields, region, countries, climates. Such ravages also depend upon the particular species of birds in a specific area. The grain crops like other fruit crops are at most risk of the attack of vertebrate pests. The bird pests damage during the early ripening stages of maize and sunflower because at that stages the seeds are milky (Cummings et al., 1989; Klosterman et al., 2012). Ripening corn is more vulnerable to bird pests which damage from the milk stage through harvest (Mitchell and Linehan, 1967). Most birds peck the center of immature kernels and remove the soft contents. It may cause kernel loss as well as mold, fungus or insects entered through the opened husks. Fruits such as grapes, cherries, an apple and majority of berries are at the risk of avian pest attack (Wright and Brough, 1966; Simon, 2008). In a study by Way (1968) noticed more than $90 \%$ damages in cherry fields. Upshall (1943) recorded 0.5-10\% losses, while blueberry farmers observed $30 \%$ damage by bird pests in Northeastern United States. Rizvi et al. (2002) and
Shafi et al. (1986) reported 2-11\% crop damage caused by house sparrow at the maturity stages of the crop. Shafi et al. (1986) also declared house crow (Corvus splendens), rose-ringed parakeet (Psittacula krameri), common myna (Acridotheres tristris), rosy starling (Sturnus roseus) and house sparrow (Passer domesticus) as pestiferous species responsible for the serious crop damages and economic losses.

With many folds growing demand for food and fruits for an increasing human population, there is a dire need to raise per capita production. This could be only possible by introducing, and launching recent strategies for pest control (Witmer, 2007). In the past agro-ecosystems and agricultural resources were protected from various vertebrate pests only by mechanical and chemical ways (Ahmad et al., 2012). Due to the bird's habituation to mechanical repellents, different chemical compounds were now used to test their repellency effects since 1960. Chemical repellents are already under assessment at a significant level in United State to reduce agricultural crop damage by bird pests (Avery et al., 1996; Gill et al., 1999; Askham, 2000; Cummings et al., 2011). Such avian repellent should be environmentally friendly and easily extractable from natural sources. This project was planned to detect a relative efficacy of natural avian repellents like methylanthranilate and anthraquinone applied to maize seeds and seedlings against house sparrows in captivity.

\section{Material and Methods}

In two large bird cages $(12 \mathrm{~L} \times 12 \mathrm{~W} \times 8 \mathrm{H}$ feet $)$, the food choice experiment was completed to evaluate the relative efficacy of methylanthranilate and anthraquinone against the house sparrow (Passer domesticus) in the area of Zoological Research Station at Botanical Garden, Government College University Faisalabad, Pakistan, from December, 2014 through March, 2015. In this locality there was a rather unobstructed and natural environment. Twenty house sparrows shaving different sexes and ages were captured, tagged and released in two aviaries (large bird cages), ten in the aviary-I regarded as a trial group while another ten in aviary-II were designated as control. Weight of each bird was recorded before the start of experiment and on the termination of experiment.

Initially in, both the aviaries the maintenance diet consisting of cereal grains, garden plants, vegetables, fruits, wheat and maize seeds were provided ad libitum to the birds during a period of one week of acclimatization. Water was accessible, ad libitum to birds all the time. Bamboos sticks and tree branches were also hanged in both the aviaries for perching and roosting the birds.

As the both bird repellents do not dissolve in water, $12.5 \mathrm{~mL}$ acetone was taken commercial adhesive and solvent and four concentrations $0.25 \%, 0.5 \%, 0.75 \%$ and $1.0 \%$ of both registered chemical repellents viz. anthraquinone (A90004/ALDRICH), naturally found in tomatoes and methylanthranilate (W268208/ALDRICH), in grapes and mint were prepared. For treating the $250 \mathrm{~g}$ of maize seeds, $62.5 \mathrm{~mL}$ of each concentration having acetone was 
taken in a beaker and stirred well with the help of electric shaker. Maize seeds treated with each concentration were air-dried and kept in darkness in cold conditions in the laboratory. A slight change in the color of maize seeds after treatment was noticed.

In the early morning, for about three hours, known quantity of maize seeds treated with each concentration of both chemical repellents was offered to the birds in a trial group and the same quantity of seeds was provided to the control group while maintenance diet was given in the remaining hours of the day. Maize seeds were examined for any physical change and no change in color was noticed. Every day unconsumed maize seeds were collected and weighed, by this consumed quantity of maize seeds in the trial and control groups was estimated daily. After one-day gape, seeds treated with each concentration were provided to the house sparrows for three consecutive days. To evaluate the difference in seed weight due to a dryness, the equivalent quantity of seeds was kept in a bowl in a small vacant cage.

At the end of experiment, to evaluate the effectiveness of both chemical repellents on maize seedlings against house sparrows' seeds was first grown in the pots. Four pots with known numbers of maize seedlings sprayed with said concentration of both bird repellents were provided to the birds in trial group and similarly four pots with unsprayed counted maize seedlings were also given to the control group in the early morning for about three hours and in the remaining hours' maintenance diet was provided to both groups. In the opposite corners of each aviary, two closed circuit cameras were adjusted in such a way to focus on the behavioral responses after feeding on untreated and treated maize seeds and seedlings with different dosages of both chemical repellents.

Daily percentage consumption of maize seeds in grams and seedlings in numbers was determined in both trial and control groups and data obtained was statistically evaluated by analysis of variance (ANOVA; Keppel, 1973 ) to appraise the difference in consumption between untreated and treated maize seeds and seedlings with said concentrations of both chemical repellents. To show the significant difference between the means LSD test was performed and t-test was performed to compute a change in body weight in the trial and control birds. All analyses were performed by using software Statistica 8.0.

\section{Results}

Maize seeds: Highly significant $(\mathrm{P}<0.01)$ differences were found between treatment $(\mathrm{T})$ and control $(\mathrm{C})$ group while significant differences $(\mathrm{P}<0.05)$ were observed in chemical repellents $(\mathrm{Ch})$ when maize seeds treated with all four different concentrations were presented to the birds in aviaries. A highly significant differences were observed among treatment and chemicals $(\mathrm{T} \times \mathrm{Ch})$ and in concentration, chemicals and treatment $(\mathrm{T} \times \mathrm{Ch} \times \mathrm{C})$. When caged sparrows were provided with the maize seeds treated, a non-significant difference was observed with different concentrations (C) of anthraquinone and methylanthranilate, which showed that all concentrations are equally effective to repel the sparrows to consume maize seeds, there also existed a non-significant difference between the interaction of concentrations and treatment and between chemicals and concentrations (Table 1).

Anthraquinone was found to be a more effective natural bird repellent when compared to methylanthranilate because consumption of maize seeds treated with anthraquinone was low (14.76 $\pm 1.06 \mathrm{~g})$ while $24.13 \pm 1.57 \mathrm{~g}$ for methylanthranilate. Mean consumption of maize seed treated with both chemical repellents in the trial and the control group was as $19.44 \pm 1.34$ and $36.47 \pm 1.10 \mathrm{~g}$ respectively (Tables 2). Among different concentrations of anthraquinone the lowest consumption was $13.02 \pm 1.51 \mathrm{~g}$ at $0.75 \%$, while the highest $16.49 \pm 3.34 \mathrm{~g}$ at $0.25 \%$ and similarly with methylanthranilate being the lowest maize seed consumption $22.19 \pm 0.90 \mathrm{~g}$ at $0.75 \%$ and highest $32.15 \pm 1.13$ at $0.25 \%$ methylanthranilate. It showed the $0.75 \%$ dose of both chemical repellent was the most effective (Table 3 and Figure 1).

Table 1. Analysis of variance for two chemical repellents (anthraquinone and methylanthranilate) against house sparrows on maize seeds(g) and seedlings (n) consumption.

\begin{tabular}{|c|c|c|c|c|c|c|c|}
\hline \multirow{2}{*}{$\begin{array}{l}\text { Source of } \\
\text { variation }\end{array}$} & \multirow{2}{*}{$\begin{array}{l}\text { Degree of } \\
\text { freedom }\end{array}$} & \multicolumn{3}{|c|}{ Maize Seeds } & \multicolumn{3}{|c|}{ Maize Seedlings } \\
\hline & & $\begin{array}{l}\text { Sum of } \\
\text { squares }\end{array}$ & $\begin{array}{c}\text { Mean } \\
\text { squares }\end{array}$ & F-value & $\begin{array}{l}\text { Sum of } \\
\text { squares }\end{array}$ & $\begin{array}{c}\text { Mean } \\
\text { squares }\end{array}$ & F-value \\
\hline Treatment (T) & 1 & 3480.93 & 3480.93 & $191.87 * *$ & 674.7 & 674.7 & $99.97 * *$ \\
\hline Chemical (Ch) & 1 & 108 & 108 & $5.95 *$ & 0.03 & 0.026 & $0.00^{\mathrm{NS}}$ \\
\hline Concentration $(\mathrm{C})$ & 3 & 57.74 & 19.25 & $1.06^{\mathrm{ns}}$ & 74.54 & 24.846 & $3.68 *$ \\
\hline $\mathrm{T} \times \mathrm{Ch}$ & 1 & 486.67 & 486.67 & $26.83 * *$ & 47.08 & 47.084 & $6.98 *$ \\
\hline $\mathrm{T} \times \mathrm{C}$ & 3 & 157.1 & 52.37 & $2.89^{\text {ns }}$ & 44.85 & 14.95 & $2.22^{\mathrm{ns}}$ \\
\hline $\mathrm{Ch} \times \mathrm{C}$ & 3 & 31.46 & 10.49 & $0.58^{\mathrm{ns}}$ & 11.69 & 3.895 & $0.58^{\mathrm{ns}}$ \\
\hline $\mathrm{T} \times \mathrm{Ch} \times \mathrm{C}$ & 3 & 245.95 & 81.98 & $4.52 * *$ & 3.16 & 1.052 & $0.16^{\mathrm{ns}}$ \\
\hline Error & 32 & 580.54 & 18.14 & & 215.97 & 6.749 & \\
\hline Total & 47 & 5148.38 & & & 1072.01 & & \\
\hline
\end{tabular}

${ }_{\mathrm{ns}}=$ Non-significant $(\mathrm{P}>0.05) ; *$ Significant $(\mathrm{P}<0.05) ; * *$ highly significant $(\mathrm{P}<0.01)$. 
Table 2. Mean consumption of maize seeds ( $\mathrm{g}$ ) and seedlings (n) when treated with anthraquinone and methylanthranilate by house sparrows.

\begin{tabular}{|c|c|c|c|c|}
\hline \multirow[b]{2}{*}{ Chemicals } & \multicolumn{2}{|c|}{ Maize Seeds } & \multicolumn{2}{|c|}{ Maize Seedlings } \\
\hline & $\begin{array}{c}\text { Trial } \\
\text { group }\end{array}$ & $\begin{array}{c}\text { Control } \\
\text { group }\end{array}$ & $\begin{array}{c}\text { Trial } \\
\text { Group }\end{array}$ & $\begin{array}{c}\text { Control } \\
\text { group }\end{array}$ \\
\hline Anthraquinone & $14.76 \pm 1.06 \mathrm{c}$ & $38.16 \pm 1.24 a$ & $17.83 \pm 0.94 b$ & $23.34 \pm 0.66 a$ \\
\hline Methylanthranilate & $24.13 \pm 1.57 b$ & $34.79 \pm 1.73 a$ & $15.89 \pm 0.83 b$ & $25.37 \pm 0.80 \mathrm{a}$ \\
\hline Means & $19.44 \pm 1.34 \mathrm{~B}$ & $36.47 \pm 1.10 \mathrm{~A}$ & $16.86 \pm 0.65 \mathrm{~B}$ & $24.36 \pm 0.55 \mathrm{~A}$ \\
\hline
\end{tabular}

Means sharing similar letter in a row or in a column are statistically non-significant $(\mathrm{P}>0.05)$. Small letters represent comparison among interaction means and capital letters are used for overall mean.

Table 3. Means for consumption of maize seeds (g) and seedlings (n) when treated with four different concentrations of anthraquinone (AQ) and methylanthranilate (MA) chemical repellents.

\begin{tabular}{|c|c|c|c|c|c|}
\hline \multirow{2}{*}{\multicolumn{2}{|c|}{ Chemical Concentration }} & \multicolumn{2}{|c|}{ Maize Seeds } & \multicolumn{2}{|c|}{ Maize Seedlings } \\
\hline & & \multirow{2}{*}{$\begin{array}{c}\begin{array}{c}\text { Trial } \\
\text { group }\end{array} \\
16.49 \pm 3.34 \mathrm{ef}\end{array}$} & \multirow{2}{*}{$\begin{array}{c}\begin{array}{c}\text { Control } \\
\text { group }\end{array} \\
40.51 \pm 0.41 \mathrm{a}\end{array}$} & \multirow{2}{*}{$\begin{array}{c}\begin{array}{c}\text { Trial } \\
\text { group }\end{array} \\
20.35 \pm 1.32\end{array}$} & \multirow{2}{*}{$\begin{array}{c}\begin{array}{c}\text { Control } \\
\text { group }\end{array} \\
23.70 \pm 1.47\end{array}$} \\
\hline $\mathbf{A Q}$ & $0.25 \%$ & & & & \\
\hline & $0.50 \%$ & $14.60 \pm 1.37 f$ & $39.77 \pm 0.95 \mathrm{ab}$ & $18.44 \pm 1.43$ & $22.01 \pm 1.54$ \\
\hline & $0.75 \%$ & $13.02 \pm 1.51 \mathrm{f}$ & $37.09 \pm 1.02 \mathrm{a}-\mathrm{d}$ & $16.93 \pm 1.73$ & $23.36 \pm 0.68$ \\
\hline & $1.00 \%$ & $14.92 \pm 2.51 \mathrm{f}$ & $35.26 \pm 4.81 \mathrm{a}-\mathrm{d}$ & $15.58 \pm 2.52$ & $24.31 \pm 1.75$ \\
\hline \multirow[t]{4}{*}{ MA } & $0.25 \%$ & $32.15 \pm 1.13 \mathrm{~cd}$ & $30.03 \pm 5.28 \mathrm{~d}$ & $19.50 \pm 1.10$ & $27.21 \pm 0.81$ \\
\hline & $0.50 \%$ & $22.77 \pm 0.59 \mathrm{e}$ & $32.93 \pm 2.93 \mathrm{bcd}$ & $16.06 \pm 1.26$ & $24.93 \pm 1.95$ \\
\hline & $0.75 \%$ & $22.19 \pm 0.90 \mathrm{e}$ & $38.16 \pm 1.82 \mathrm{abc}$ & $14.25 \pm 1.01$ & $23.17 \pm 2.03$ \\
\hline & $1.00 \%$ & $19.40 \pm 2.30 \mathrm{ef}$ & $38.03 \pm 1.55 \mathrm{abc}$ & $13.77 \pm 1.16$ & $26.17 \pm 1.02$ \\
\hline
\end{tabular}

Means sharing similar letter in a row or in a column are statistically non-significant $(\mathrm{P}>0.05)$. Small letters represent comparison among interaction means and capital letters are used for overall mean.

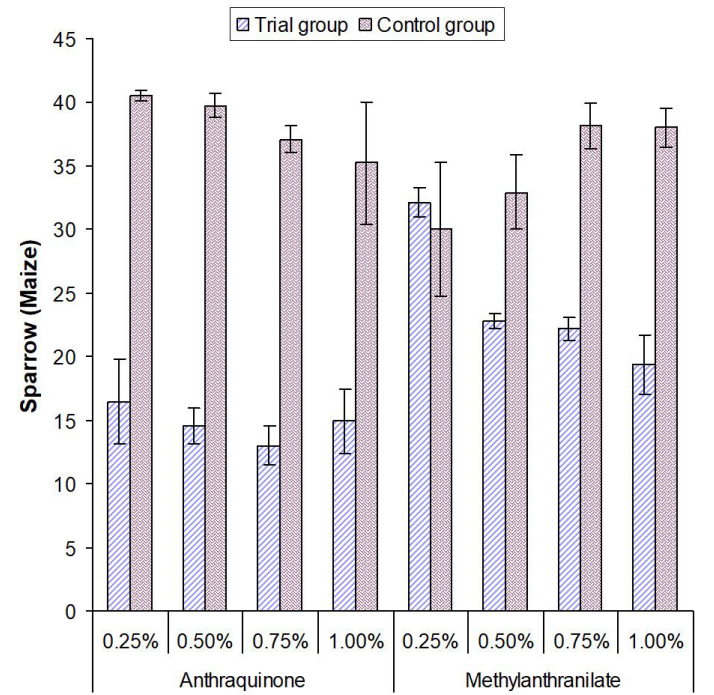

Figure 1. Effectiveness of anthraquinone and methylanthranilate on maize seeds.

Maize seedlings: A highly significant $(\mathrm{P}<0.01)$ differences were noticed in trial and control groups when maize seedlings were provided to sparrows. A significant $(\mathrm{P}<0.05)$ difference was noticed in different concentrations of both natural repellents (Table 1). Non-significant $(\mathrm{P}>0.05)$ differences were found between the two bird repellents $(\mathrm{Ch})$, between the interaction of treatment and chemical $(\mathrm{T} \times \mathrm{Ch})$, chemical and between concentration $(\mathrm{Ch} \times \mathrm{C})$ and concentration, chemical and treatment $(\mathrm{T} \times \mathrm{C} \times \mathrm{Ch})$ for the consumption of maize seedlings by house sparrows. The consumption of maize seedlings treated with anthraquinone and methylanthranilate was $17.83 \pm 0.94$ and $15.89 \pm 0.83$, respectively, which exhibited non-significant differences. The seedling consumption for both repellents in the trial and the control group was $16.86 \pm 0.65$ and $24.36 \pm 0.55$, respectively (Table 2 ) and the $1 \%$ concentration of both repellents showed more repellency (Table 3, Figure 2). Statistical analyses clearly revealed that use of natural repellents did not influence the weight of birds and birds in captivity sustained body mass and health after feeding trials (Table 4).

\subsection{Videotapes behaviour}

In each large bird cage with two closed circuit cameras was adjusted to monitor the behavioural responses against the house sparrows when provided different doses of chemical repellents. It was observed that birds quickly prejudiced by consuming maize seeds treated with higher concentrations of methylanthranilate and anthraquinone and resultantly less consumption of seeds in trial group. Feather rumpling and head trembling was also perceived when sparrows consumed maize seeds treated with higher concentrations. After initial 25 minutes' exposure to repellents some also showed symbols of disquiet and queasiness. No sign of change in physical fitness and body weight of house sparrows was observed throughout the experiment. 
Table 4. Comparison of means between house sparrow weight $(\mathrm{g})$ in control and trial group at the start and end of the experiment.

\begin{tabular}{lccccccc}
\hline & Group & N & Mean & SD & SE & t-value & Prob. \\
\hline Sparrow initial weight & Trial & 10 & 22.94 & 3.91 & 1.24 & $0.42^{\text {ns }}$ & 0.678 \\
& Control & 10 & 22.17 & 4.25 & 1.34 & & 0.780 \\
Sparrow final weight & Trial & 10 & 21.62 & 3.99 & 1.26 & $0.28^{\text {ns }}$ & 0.780 \\
& Control & 10 & 21.09 & 4.35 & 1.38 & & 0.519 \\
Sparrow weight decrease & Trial & 10 & 1.32 & 0.89 & 0.28 & $0.66^{\text {ns }}$ & 0.23 \\
& Control & 10 & 1.08 & 0.74 & 0.23 & & \\
\hline
\end{tabular}

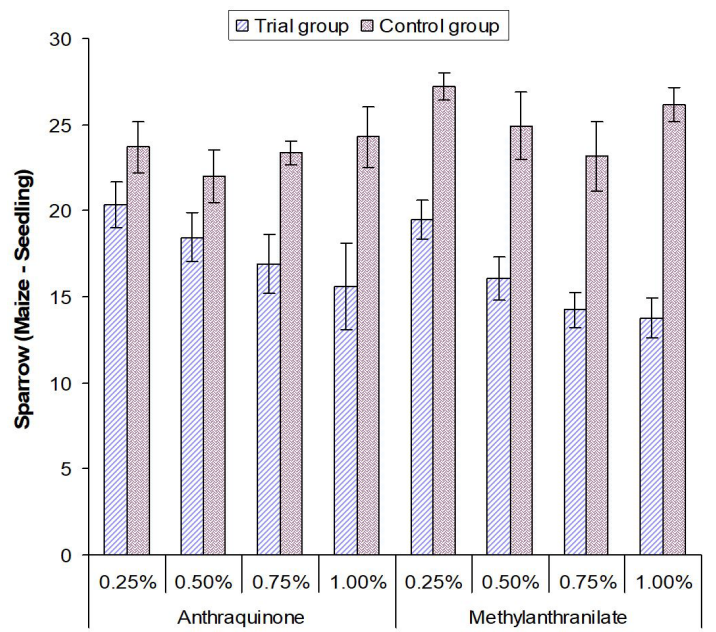

Figure 2. Effectiveness of anthraquinone and methylanthranilate on maize seedlings.

\section{Discussion}

The present caged study proved the repellent properties of methylanthranilate and anthraquinone against house sparrows when maize seeds and seedlings treated with different concentrations were offered to the birds. Higher seed consumption in a control group (aviary-II) as compared with a trial group (aviary-I), showed highly significant results about the effectiveness of both methylanthranilae and anthraquinone bird repellents against the house sparrows when treated seeds and seedlings were provided. Such results proved the restraining possessions of both these chemical repellents against this bird species. Anthraquinone was statistically more effective repellent than methlyanthranilate in case of maize seeds: similar results were observed by Avery et al. (2001), Werner et al. (2009, 2011), and Esther et al. (2013) against different bird pests.

In the second phase of experiments when maize seedlings grown in the pots were provided to the caged sparrows a non-significant difference $(\mathrm{P}>0.05)$ was observed between both the chemical repellents which showed that both repellents have equal deterring effects. Our results are not in agreement with the finding of Kennedy and Connery (2008) who found reverse results with pigeons and crows in field. They also demonstrated that both deterrent substances were found useless for pigeons and crows.
The body weight of sparrows in the trial group (aviary-I) was not significantly different throughout the experiment, which confirmed the Avery et al. 1993 findings, however, insignificant queasiness behavior, aching, and sickness was observed in some birds only during videotaped observation. Avery et al. $(1993,1996,2001)$ and Mason and Bonwell (1993) studies on grackle, red-winged blackbirds and brown-headed cowbirds certified the results obtained with treatment of turpentine, insecticide, mint derivatives and methylanthranilate. The evaluation of these chemical repellents in the field research under natural conditions and cost benefit analysis is urgently required against the bird pests. Feather ruffling and head shaking in sparrows by eating maize seeds treated with higher concentrations of both chemical repellents also observed during present studies and these results are very much coinciding with videotaped observations on red-winged blackbird and boat-tailed grackles when provided with $1.0 \%$ polygon.

According to Cummings et al. (1998), Avery et al. (2001), and Werner et al. (2009) different bird pests like yellow-headed blackbirds, Canada geese, common grackles European starlings, American kestrels, cedar waxwings, house sparrows, mallards and feral pigeons when provided with treated seeds by methylanthranilate and anthraquinone the reduction in seed consumption was observed and these observations confirmed the present findings.

\section{Conclusions}

Present results verified that methylanthranilate and anthraquinone have the repellent potential against the house sparrow on maize seeds and seedlings in caged conditions and furthermore, $0.75 \%$ and $1 \%$ concentrations of both chemical repellents are more effective. It is suggested that these repellents can further be tested in field studies in crop area of Pakistan.

\section{Acknowledgements}

The authors have immense tributes for the financial assistance of Higher Education Commission, Islamabad, Pakistan, to accomplish the present research project (HEC Project\# PM-IPFP/HRD/HEC/2012/3559). The authors (KAA and SM) would like to express their sincere appreciation to the Deanship of Scientific Research at King Saud University for its funding of this research through the Research Group Project No. RGP-1435-012. 


\section{References}

AHMAD, S., KHAN, H.A., JAVED, M. and REHMAN, K.U., 2012. Management of maize and sunflower against the depredations of rose-ringed parakeet (Psittaculakrameri) using mechanical repellents in an agro-ecosystem. International Journal of Agriculture and Biology, vol. 14, pp. 286-290.

AHMAD, S., SALEEM, Z., JABEEN, F., KHAN, H.A., YAQUB, S., SAMIULLAH, K., MUBARIK, S., IRFAN, M. and SHAHEEN, T., 2016. Effectiveness of methylanthranilate and anthraquinone as repellent against house crows (Corvus splendens) on wheat seeds and seedlings in captivity. Pakistan Journal of Zoology, vol. 48 , no. 5 , pp. 1591-1594

ASKHAM, L.R. 2000. Efficacy of the aerial application of methyl anthranilate in reducing bird damage to sweet corn, sunflowers, and cherries. In: T.P. SALMON and A.C. CRABB, eds. Proceedings of the vertebrate pest conference. Davis: University of California, vol. 19 , pp. 22-25.

AVERY, M.L., DECKER, D., HUMPHREY, J.S. and LAUKERT, C.C., 1996. Mint plant derivatives as blackbird feeding deterrents. Crop Protection, vol. 15, no. 5, pp. 461-464. http://dx.doi. org/10.1016/0261-2194(96)00010-5.

AVERY, M.L., DECKER, D.G., FISCHER, D.L. and STAFFORD, T.R., 1993. Responses of blackbirds to a new insecticidal seed treatment. The Journal of Wildlife Management, vol. 57, no. 3, pp. 652-656. http://dx.doi.org/10.2307/3809296.

AVERY, M.L., TILLMAN, E.A. and LAUKERT, C.C., 2001. Evaluation of chemical repellents for reducing crop damage by dickcissels in Venezuela. International Journal of Pest Management, vol. 47, no. 4, pp. 311-314. http://dx.doi.org/10.1080/09670870110065235.

CUMMINGS, J.L., BYRD, R.W., EDDLEMAN, W.R., ENGEMAN, R.M. and TUPPER, S.K., 2011. Effectiveness of AV-10111 to reduce damage to drill-planted rice from blackbirds. The Journal of Wildlife Management, vol. 75, no. 2, pp. 353-356. http://dx.doi. org/10.1002/jwmg.65.

CUMMINGS, J.L., CLARK, L., POCHOP, P.A. and DAVIS, J.E., 1998. Laboratory evaluation of a methyl anthranilate bead formulation on mallard feeding behaviour. The Journal of Wildlife Management, vol. 62, no. 2, pp. 581-584. http://dx.doi. org/10.2307/3802332

CUMMINGS, J.L., GUARINO, J.L. and KNITTLE, C.E., 1989. Chronology of blackbird damage to sunflowers. Wildlife Society Bulletin, vol. 17, pp. 50-52.

ECONOMIC SURVEY OF PAKISTAN, 2013. Pakistan Economic Survey of Pakistan 2012-13. Islamabad: Govt. of Pakistan, Econ. Advisor's Wing, Finance Division.

ESTHER, A., TILCHER, R. and JACOB, J., 2013. Assessing the effects of three potential chemical repellents to prevent bird damage to corn seeds and seedlings. Pest Management Science, vol. 69, no. 3, pp. 425-430. PMid:22499556. http://dx.doi. org/10.1002/ps.3288.

GILL, E.L., COTTERILL, J.V., COWMAN, D.P., GREY, C.B., GURNEY, J.E., MOORE, N.P., NADIAN, A.K. and WATKINS, R.W. 1999. All in the worst possible taste: chemical repellents in vertebrate pestmanagement. In: D.P. COWAN \& C.J. FEARE, eds. Advances in vertebrate pest management. Fürth: FilanderVerl, pp. 283-295.

KENNEDY, T.F. and CONNERY, J., 2008. An investigation of seed treatments for the control of crow damage to newly-sown wheat. Irish Journal of Agricultural and Food Research, vol. 47, pp. 79-91.
KEPPEL, G. 1973. Design and analysis: a researcher's handbook. Englewood Cliffs: Prentice-Hall.

KLOSTERMAN, M.E., LINZ, G.M., SLOWIK, A.A. and BLEIER, W.J. 2012. Assessment of Bird Damage to Sunflower and Corn in North Dakota. In: S.N. FREY, ed. Proceedings of the 14th WDM Conference, 2012, Kyoto, Japan. New Jersey: IEEE Press Piscataway, pp. 119-123.

LINZ, G.M. and HANZEL, J.J. 1997. Birds and sunflower. In: A.A. SCHNEITER, ed. Sunflower technology and production. Madison: American Society of Agronomy, Crop Science Society of America, and Soil Science Society of America, pp. 381-394. Agronomy Monograph no. 35.

MASON, J.R. and BONWELL, W.R., 1993. Evaluation of turpentine as a bird-repellent seed treatment. Crop Protection, vol. 12, no. 6, pp. 453-457. http://dx.doi.org/10.1016/0261-2194(93)90007-6.

MITCHELL, R.T. and LINEHAN, J.T. 1967. Protecting corn from blackbirds. Washington: U.S. Fish and Wildlife Service, 8 p. Wildlife Leaflet, no. 476

RIZVI, S.W.A., PERVEZ, A. and AHMED, S.M., 2002. Evaluation of methiocarb $50 \%$-WP as a taste repellent against the house Sparrow (Passer domesticus l.). Turkish Journal of Zoology, vol. 26, pp. 131-135.

SCHÄCKERMANN, J., WEISS, N., VON WEHRDEN, H. and KLEIN, A.-M., 2014. High trees increase sunflower seed predation by birds in an agricultural landscape of Israel. Frontiers in Ecology and Evolution, vol. 2, pp. 35. http://dx.doi.org/10.3389/ fevo.2014.00035.

SHAFI, M.M., KHAN, A.A. and HUSSAIN, I., 1986. Parakeet damage to citrus fruit in Punjab. Journal of the Bombay Natural History Society, vol. 83, pp. 439-444.

SIMON, G., 2008. A short overview of bird control in sweet and sour cherry orchards: possibilities of protection of bird damage and its effectiveness. International Journal of Horticultural Science, vol. 14 , no. $1-2$, pp. 107-111.

TOLLENAAR, M. and DWYER, L.M. 1999. Physiology of maize. In: D.L. SMITH and C. HAMEL, eds. Crop physiology and processes. Heidelberg: Springer Verlag, pp. 169-199.

UPSHALL, W.H. 1943. Fruit maturity and quality. Ontario: Department of Agriculture, 447 p. Food Bulletin.

WAY, R.D. 1968. Breeding for superior cherry cultivars in New York State. In: Proceedings of the ISHS Symposium on Cherries and Cherry Growing, 1968, Bonn, Germany. Bonn: ISHS, pp. 121-137.

WERNER, S.J., CARLSON, J.C., TUPPER, S.T., SANTER, M.M. and LINZ, G.M., 2009. Threshold concentrations of an anthraquinone-based repellent for Canada geese, red-winged blackbirds, and ring-necked pheasants. Applied Animal Behaviour Science, vol. 121, no. 3-4, pp. 190-196. http://dx.doi.org/10.1016/j. applanim.2009.09.016.

WERNER, S.J., LINZ, G.M., CARLSON, J.C., PETTIT, S.E., TUPPER, S.K. and SANTER, M.M., 2011. Anthraquinone-based bird repellent for sunflower crops. Applied Animal Behaviour Science, vol. 129, no. 2-4, pp. 162-169. http://dx.doi.org/10.1016/j. applanim.2010.11.010.

WITMER, G.W. 2007. The ecology of vertebrate pests and integrated pest management (IPM). In: M. KOGAN and P. JEPSON, eds. Perspectives in ecological theory and integrated pest management. Cambridge: Cambridge University Press, pp. 393-410.

WRIGHT, E.N. and BROUGH, T. 1966. Bird damage to fruit. In: P.M. SYNGE and E. PAPIER, eds. Fruit present and future. RHS/Bles., pp. 168-180. 